\title{
New insights to assess the consolidation of stone materials used in built heritage: the case study of ancient graffiti (Tituli Picti) in the archaeological site of Pompeii
}

\author{
Silvestro Antonio Ruffolo ${ }^{*}$, Natalia Rovella ${ }^{{ }^{*}}$, Anna Arcudi ${ }^{1}$, Vincenza Crupi ${ }^{2}$, Domenico Majolino ${ }^{2}$, \\ Massimo Osanna ${ }^{3}$, Rossella Pace ${ }^{4}$, Alessia Pantuso ${ }^{1}$, Luciana Randazzo ${ }^{1}$, Michela Ricca ${ }^{1}$, Nicola Ruggieri ${ }^{5}$, \\ Valentina Venuti ${ }^{2}$ and Mauro Francesco La Russa ${ }^{1}$
}

\begin{abstract}
Tituli Picti are an ancient form of urban graffiti very common in the archaeological site of Pompeii (Naples, SouthItaly). They are generally made of red pigments applied on walls of Campanian ignimbrite. This paper deals with a scientific investigation aimed to their conservation. This is a challenging task since it requires a multidisciplinary approach that includes restorers, archaeologists and conservation scientists. The study has provided suggestions on the proper way to conserve Tituli Picti over time. In the present work, several specimens of Campanian ignimbrite were painted with red earth pigment; lime and Arabic gum have been used as binders as well. Such painted stones were treated with three consolidants: a suspension of reactive nanoparticles of silica, ethyl silicate and an acrylic microemulsion. Treated and untreated specimens were subjected to thermal aging, artificial solar radiation and induced crystallization decay. It has been assessed the colorimetric variations induced by treatments. Moreover, the micromorphologic features of the consolidated surfaces have been highlighted by means of electron microscope observations. The scotch tape test allowed to compare the superficial cohesion induced by the three used products. According to the results, ethyl silicate seems to represent the most successful product.
\end{abstract}

Keywords: Tituli Picti of Pompeii, Conservation, Consolidation

\section{Introduction}

Pompeii is considered one of the most important archaeological site in the world, it represents a popular tourist attraction in Southern Italy, counting about 3.6 million visitors in 2018 [1]. The archaeological site of Pompeii belongs to the UNESCO World Heritage and it extends up to about 66 hectares (22 hectares still remain unexcavated). The ancient city of Pompeii is located on a plateau formed by the Vesuvius volcano's lava flow, near Naples

\footnotetext{
*Correspondence: silvestro.ruffolo@unical.it; natalia.rovella@unical.it 1 Department of Biology, Ecology and Earth Sciences, University of Calabria, via P. Bucci Cubo 12B, Arcavacata di Rende, CS 87036, Italy Full list of author information is available at the end of the article
}

[2]. Information about the origin of the city is uncertain. Researchers believe that the town was founded in the 7th-6th century $\mathrm{BC}$ by the Oscans. It came under the domination of Rome in the 4th century $\mathrm{BC}$ and was conquered and became a Roman colony in $80 \mathrm{BC}$ after it joined an unsuccessful rebellion against the Roman Republic [3]. The city was unexpectedly buried in the thick layer of ash and lava from the devastating eruption of Vesuvius of $79 \mathrm{AD}$. Re-emerged from the darkness of centuries at the beginning of the 16th century, during remediation works in the Sarno Valley [4], it is one of the most significant proofs of Roman civilization. It is divided into several Regio (neighborhoods) and Insulae (blocks) and each house is identified with Regio, Insulae,
Springer Open

(c) The Author(s) 2020. This article is licensed under a Creative Commons Attribution 4.0 International License, which permits use, sharing, adaptation, distribution and reproduction in any medium or format, as long as you give appropriate credit to the original author(s) and the source, provide a link to the Creative Commons licence, and indicate if changes were made. The images or other third party material in this article are included in the article's Creative Commons licence, unless indicated otherwise in a credit line to the material. If material is not included in the article's Creative Commons licence and your intended use is not permitted by statutory regulation or exceeds the permitted use, you will need to obtain permission directly from the copyright holder. To view a copy of this licence, visit http://creativecommons.org/licenses/by/4.0/. The Creative Commons Public Domain Dedication waiver (http://creativecommons.org/publicdomain/zero/1.0/) applies to the data made available in this article, unless otherwise stated in a credit line to the data. 
street and number that recalls modern addresses (i.e. Via dell'Abbondanza Reg. IX Ins. I, n. 16). Walking around the streets, some writings on walls are visible, recalling the graffiti in our modern cities. These wall inscriptions (Tituli Picti) are uniqueness in the Roman archaeological heritage (Fig. 1).

Approximately 1100 Tituli Picti have been found, written in different languages: Oscan, Greek and Latin $[5,6]$. The support varies in the vast repertory offered by the Pompeii's inscriptions, from plaster to travertine, but mainly they are written on Campanian ignimbrite, which is a pyroclastic rock, having a high porosity and an high silica content; red ochre or, more rarely, black pigments are used. The widest spread dealt theme is of electoral type in which the election of a citizen to a magistrates is proposed, others are related to prohibition signals, invectives, various acclamations, inscriptions concerning in general the binomial relation love-death, property ads, ads for selling building materials, requests related to lost objects $[7,8]$. The inscriptions are generally positioned along the more intense traffic streets, where houses of many influent personalities of the Samnite and Roman town were located as well as close to the Forum, the par excellence place for politic and electoral meetings [9]. The Tituli Picti are generally located at a height of about 3-4 meters, in order to ensure a full visibility of the inscription to the potential readers and to make it difficult the overwriting as well [10].

The conservation of such inscriptions still represents a challenge in the framework of the preservation of the archaeological site. Ignimbrite is a fragile substrate

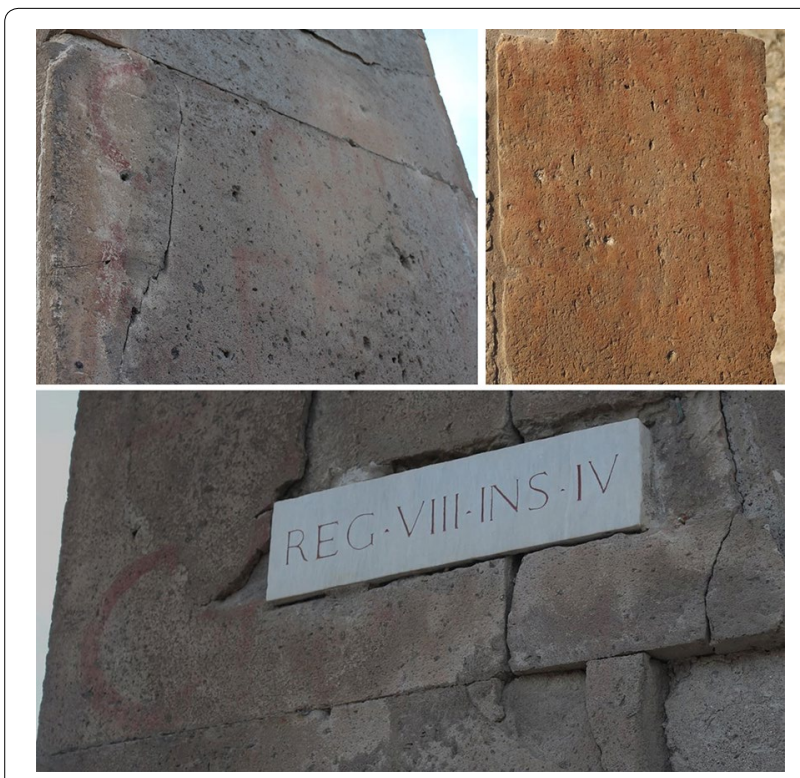

Fig. 1 Examples of Tituli Picti suffering several degradation processes [11-13]. Many Tituli Picti were studied by means of both non-invasive and micro-invasive techniques [14]. The characterization analysis highlighted the degradation phenomena affecting the ignimbrite wall panels such as biological colonization, chromatic alteration and especially efflorescence of sodium, calcium, magnesium sulphates, nitrates and chlorides able to damage seriously the microstructure of the rock until its fracturing. These processes are encouraged by the high porosity of the material promoting the uprising of the ground waters from the soil. Moreover, the partial transformation of ignimbrite in clay minerals was revealed, in which the macroscopically observed reddish colour is related to a diffuse presence of hydrated Fe-oxides. In some cases, this phenomenon can lead to a partial overlap with Tituli Picti, since they have similar colours. The study on the pigments identified a red ochre, revealing the hematite based composition, but not the presence of any binder. This suggested that the pigment was applied just by a water dispersion, but it is also possible that an organic binder, degraded over years, was used for this reason there is not any evidence.

For conservation purposes, it is essential to establish which are the best procedures to adopt in order to preserve the Tituli Picti for as long time as possible, identifying the most appropriate consolidating product.

The decay Tituli Picti consists in two processes, the first one is related to the degradation of the superficial portion of the stone which contains the pigment, while the second one is represented by the degradation of the stone itself. Therefore, both aspects have to be taken into account when the issue of Tituli Picti is faced.

For this reason, a laboratory experimentation was set up in which specimens of ignimbrite were prepared, and then a red ochre based paint with different binders (Lime and Arabic gum), and without any binder as well, was applied on such specimens. Once set-up, the painted specimens were subjected to a washout test in order to simulate the weathering due to the rainwater so leading the paints to an in situ environment that was as close to the real one. Several consolidating products were applied, and then colorimetric tests, microscopic observations, surface cohesion tests and capillary water absorption measurements were carried out to check the suitability of such treatments. In addition, salt weathering test were conducted to evaluate the bulk cohesion provided by consolidants versus salt crystallization, an important degrading process observed in the archaeological site.

\section{Materials and methods}

We used Campanian Ignimbrite for the experiments. This rock is the product of the activity of Campi Flegrei, along with the Ischia and Procida islands, a complex 
volcanic system constituted by an eastwest-oriented network of small monogenic apparatus. It is very rich in silicon and aluminium and has a porosity ranging from 35 to $43 \%$ [14]. Raw material was cut (size $5 \times 5 \times 2 \mathrm{~cm}$ ) in order to obtain the laboratory specimens. Paints mixture were prepared by mixing red ochre with water, as well as with water and several binders (lime putty, lime and Arabic gum suspensions) (Table 1). These binders were chosen, because they were very common in Roman age in mural painting [15]. An average of $0.5 \mathrm{~g}$ of each paint was applied on stone surface (about $10 \mathrm{~cm}^{2}$ ) by brush.

Samples were subjected to washout treatment for $168 \mathrm{~h}$. Tests were setup as follows: four specimens were placed in a container filled with distilled water. A magnetic bar was dropped into the water and then the container was placed on a magnetic stirrer at $1200 \mathrm{rpm}$ (Additional file 1: Fig. S1). For consolidation assessments, three commercial products were used: NanoEstel, Estel 1000, and Micro Acril (CTS, Italy). The first and the second products were chosen because they have a good chemical compatibility with stone, since both are based on silica, while the choice of the third one was suggested by restoration practice, which includes the use of organic consolidants for the conservation of paintings. NanoEstel is an aqueous suspension of reactive silica nanoparticles having an average size of $30 \mathrm{~nm}$; Estel 1000 is composed of TEOS (tetraethyl orthosilicate) diluted in white spirit (a mixture of aliphatic hydrocarbons having a boiling point of $145-250{ }^{\circ} \mathrm{C}$ ). This molecule is hydrolysed by water, then $\mathrm{SiO}_{2}$ is formed by condensation within the porous structure, which can be bonded to the stone surface, leading to a consolidating effect, this process is also known as sol-gel. Micro Acril is a water based microemulsion of acrylic polymer with a particle size of about 40 microns.

Consolidation products were applied at different concentrations of active compounds $(3,5,10,20 \% w t)$ (Additional file 1: Table S1).

Colorimetric tests were carried out using a CM-2600d Konica Minolta spectrophotometer to identify chromatic

\section{Table 1 Summary of sample preparation}

\begin{tabular}{llllll}
\hline ID & $\begin{array}{l}\text { Red } \\
\text { pigment } \\
\text { (\%wt) }\end{array}$ & $\begin{array}{l}\text { Water } \\
\text { (\%wt) }\end{array}$ & $\begin{array}{l}\text { Lime } \\
\text { putty } \\
\text { (\%wt) }\end{array}$ & Lime (\%wt) & $\begin{array}{l}\text { Arabic gum } \\
\text { suspension } \\
\text { (\%wt) }\end{array}$ \\
\hline P & 38 & 62 & - & - & - \\
PLPA & 31 & 63 & 6 & - & - \\
PLPB & 33 & 65 & 2 & - & - \\
PL & 33 & 65 & - & 2 & - \\
PAGA & 24 & 38 & - & - & 38 \\
PAGB & 38 & - & - & - & 62 \\
\hline
\end{tabular}

variations induced by the treatments. Chromatic values are expressed according to the CIE (Commission Internationale d'Eclairage) $\mathrm{L}^{*} \mathrm{a}^{*} \mathrm{~b}^{*}$ space, where $\mathrm{L}^{*}$ is the lightness/darkness coordinate, $\mathrm{a}^{*}$ the red/green coordinate ( $+\mathrm{a}^{*}$ indicating red and $-\mathrm{a}^{*}$ green), and $\mathrm{b}^{*}$ the yellow/ blue coordinate $\left(+b^{*}\right.$ indicating yellow and $-b^{*}$ blue) [16]. Measurements were carried out using a $8.0 \mathrm{~mm}$ diameter viewing aperture, specular component excluded (SCE), UV 0\%, Illuminant D65 and $10^{\circ}$ observer angle. The colour changes were expressed in terms of $\Delta \mathrm{E}[15]$ :

$$
\Delta E=\sqrt{\Delta L^{* 2}+\Delta a^{* 2}+\Delta b^{* 2}}
$$

All the given results are average values of ten measurements taken on each specimen (five on the painted area, five on the unpainted area). For each treatment, three specimens were analysed.

Capillary water absorption tests were performed to determine the amount of water absorbed by treated and untreated specimen per surface unit (Qi) over time. Qi is defined as: $\mathrm{Qi}=\left(\mathrm{mt}-\mathrm{m}_{0}\right) / \mathrm{S}$, where $\mathrm{S}$ is the area (in $\left.\mathrm{cm}^{2}\right)$ of the sample exposed to water; $\mathrm{m}_{\mathrm{t}}$ and $\mathrm{m}_{0}$ represent the weight of sample measured during the test, at the times t and 0 , respectively [17]. The test was aimed to check the hydrophobic effect induced by treatments, as well as the variation in porosity.

Microscopic observations were carried out by using a FEI Quanta 200F electron microscope (Philips). The analyses have been carried out at low vacuum regime $\left(10^{-3}\right.$ bar) and with an accelerating voltage of $20 \mathrm{kV}$.

The salt crystallization test (or salt weathering test), was performed by following the procedure described in the existing standard [18]. Specifically, specimens underwent 15 crystallization cycles consisting of: $2 \mathrm{~h}$ of immersion in a supersaturated solution of sodium sulfate $(14 \%$ $\mathrm{w} / \mathrm{w}$ at $\left.20{ }^{\circ} \mathrm{C}\right), 16 \mathrm{~h}$ of drying in an oven at $105{ }^{\circ} \mathrm{C}$, and $6 \mathrm{~h}$ of cooling at room temperature. The weight of each test sample was measured before the crystallization test and after each cycle; the resulting weight loss was determined. Each measurement has been repeated on three specimens.

The specimens were undergone to aging tests by the means of two climatic chambers. The first artificial aging process regarded the solar radiation obtained by a Suntest XLS + chamber (Atlas USA). The latter is equipped with a Xenon arc lamp, tests occurred at $26{ }^{\circ} \mathrm{C}$ and at a radiation level of $53 \%$. The total time of test was $4000 \mathrm{~h}$. After solar radiation aging, samples were hold for $1500 \mathrm{~h}$ in a temperature humidity controlled chamber, with a temperature of $45{ }^{\circ} \mathrm{C}$ and relative humidity of $70 \%$.

Peeling test is a test aimed to quantify the adhesion of a surface or a near to-surface layer to a substrate. According to the method proposed by Drdácký and co-workers 
[19], a pressure-sensitive tape was applied to the investigated area and then pulled off. It was measured the weight of material detached from the surface after peeling off the tape. The test was repeated five times on the same area. It is generally assumed that this amount reflects the cohesion characteristics of the substrate. In this specific case, the test was used to make a comparative assessment of the cohesion provided by each treatment. Measurements were performed on three samples for each treatment, as well as before treatment.

\section{Results and discussions}

By a visual inspection, all paints seem to be poor adherent to the stone; this is confirmed by washout tests, which induced a variation of the colorimetric coordinates measured on the painted layers. This is macroscopically visible, since an aliquot of the pigmented layers is removed thanks to the action of water. The pigment that penetrates inside the stone seems to be less affected by the washing action of the water. This situation is much more similar to the real situation observed in Tituli Picti: there is not any visible pigment layer on the surface, but there are just pigment grains into the stone porous structure [14]. Figure 2 shows an overview of all paints and the visible effect of the washout as well. This result highlighted that all paints are not well adherent on the stone and can be removed by weathering, leaving some pigment in the stone. For this reason, hereinafter we focussed our attention mostly on the paint made of the bare pigment.

Specimens painted with only the pigment and consolidated with the three products, and then aged, were observed by means of electron microscope (Fig. 3) to check the surface distribution of the products and assess the penetration features as well. The distribution of the consolidant was evaluated by morphological observation of the surface, since the application of the products modifies the aspect of the surface; while the penetration depth was determined by observation of cross sections of the treated samples.

In samples consolidated with NanoEstel, the product does not completely cover the surface; it appears concentrated especially into the voids. The coating appears rather compact, although it is affected by some microcracks. At the highest concentration, the product creates a homogeneous surface coating having a thickness up to $40 \mu \mathrm{m}$. The penetration depth does not exceed $20 \mu \mathrm{m}$. The application of Estel has not produced a clear surface coating, only in some points it has been possible to distinguish a significant film (up to $2 \mu \mathrm{m}$ of thickness). The penetration depth is about $20 \mu \mathrm{m}$. The Micro Acril-based
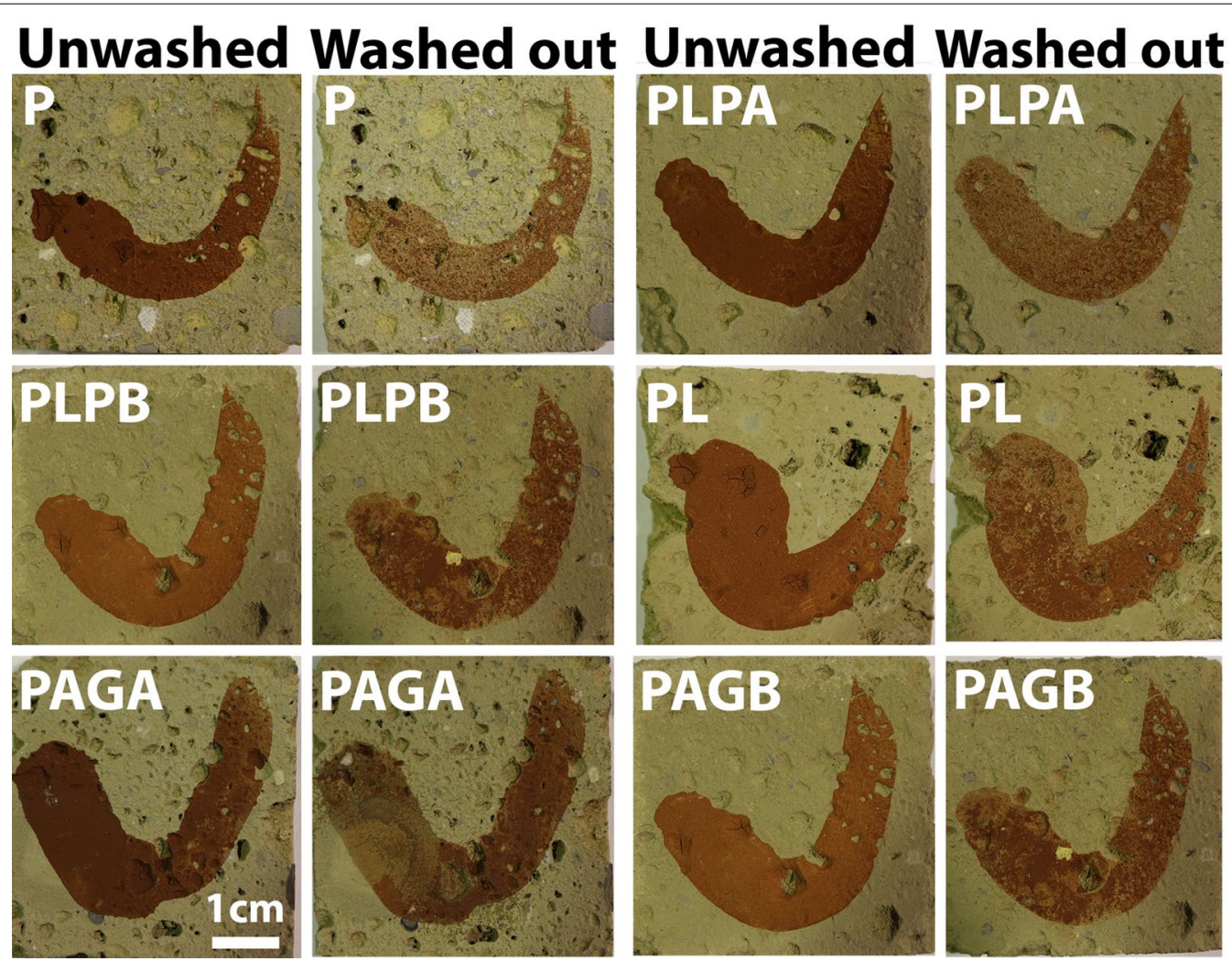

Fig. 2 Samples before and after washout test 

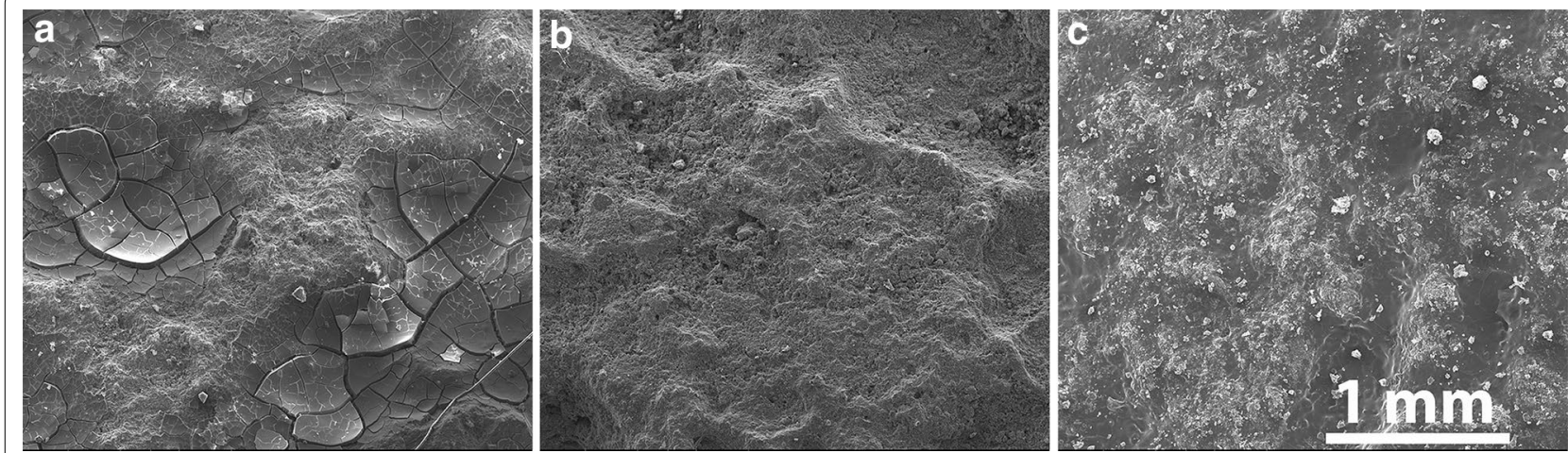

Fig. 3 SEM images of stone surface treated with a NanoEstel $\mathbf{b}$ Estel and $\mathbf{c}$ Micro Acril

treatment creates a "gloss effect" on the surface that, consequently, appear covered by a compact and homogeneous coating, and without any microfractures. In this case, a lower depth of penetration of the product is observed (up to $7 \mu \mathrm{m}$ ).

The colorimetric variations were assessed only on the paint made with the bare pigment. In Fig. 4 we showed the results of such measurements, performed both on the pigment and on the substrate. Micro Acril consolidant induces stronger chromatic variations on both pigment and substrate than Estel and NanoEstel. This could be relative to the different nature of Micro Acril: it is an organic consolidant in microemulsion, made, namely of particles, which hardly penetrate into the stone, much that cause the formation of a superficial slightly whitish film. NanoEstel showed the best behaviour on the
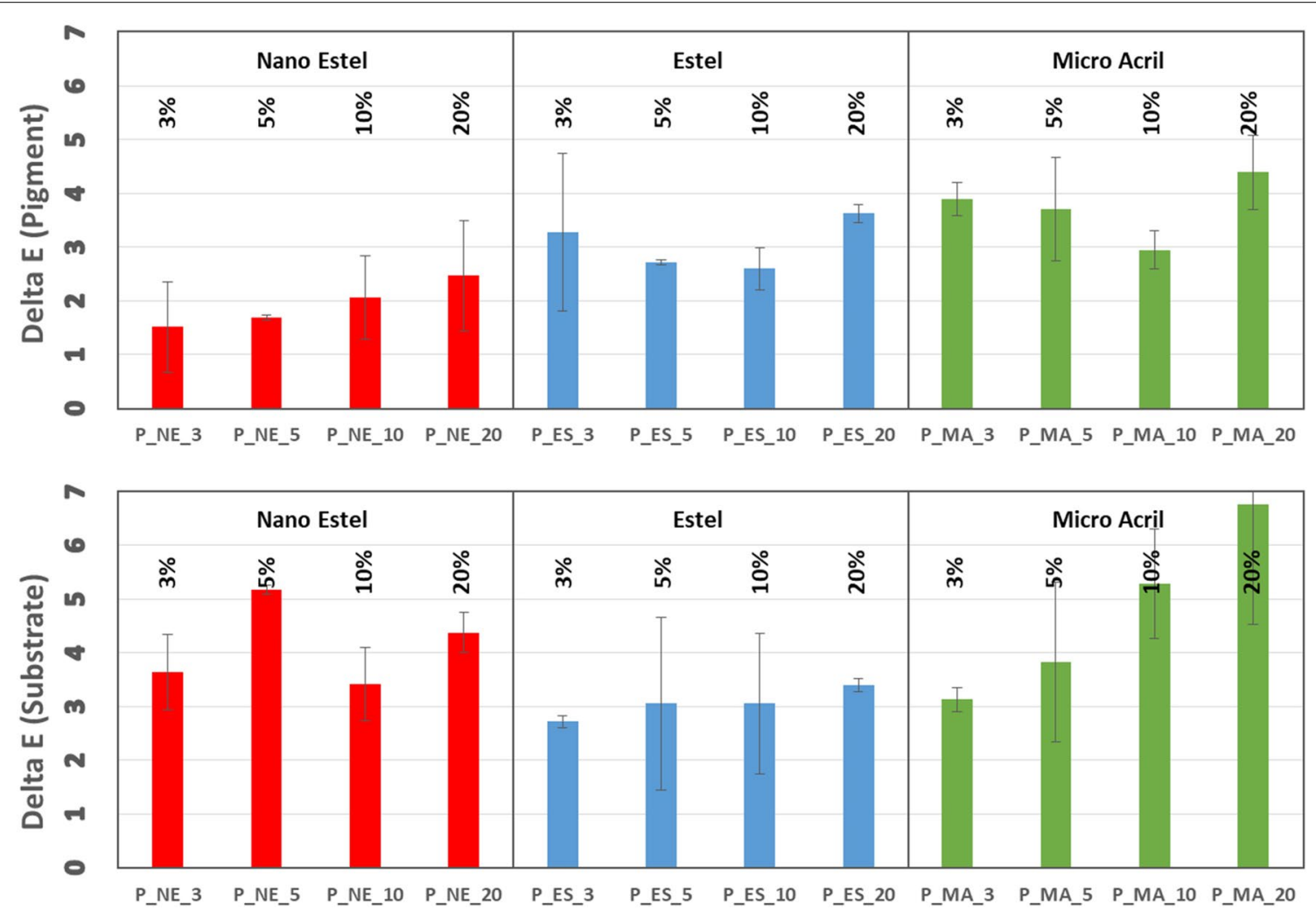

Fig. 4 Colorimetric variations induced by consolidation treatments on the painted (upper chart) and unpainted (lower chart) areas of the specimens 
pigment layer, while Estel seems to induce fewer variations in terms of colour on the substrate.

In Fig. 5, we reported the results of capillary water absorption tests performed on treated samples, for comparison the values measured for untreated specimens have been showed as well. For all treatments, the water uptake decreases as the amount of consolidant increases. This is due to two factors, the first concerns with the decrease of porosity, while the second is related to the hydrophobicity induced by the consolidant. The latter is quite evident Micro Acril treatment, since it induced the strongest decreasing of water sorption due to its organic nature. NanoEstel and Estel are inorganic product, their application behaved in similar way; it seems that they induce a mild alteration of the porosity. However, it has to be pointed out that Estel once cured has an inorganic nature, but for several months after the application, there is some solvent left into the consolidant, which provides a transient hydrophobic effect [20].

Another crucial issue concerning the conservation of the Tituli Picti is related to the possibility to provide a better resistance of the superficial portion of the stone, since it contains the pigment making visible the Tituli Picti themselves.
Thanks to the peeling test, it was possible to assess the surface cohesion of the treated stone. Measurements were performed on three typologies of specimens: bare, painted but not treated with consolidants, and consolidated. For the latter, measurements were performed before and after artificial aging.

The aging should have an effect both on the microstructure of the consolidant (i.e. cracks and loose of cohesion) and on the composition of the consolidant. This latter one would occur only in the case of Micro Acril, since it is an organic polymer. Results are summarized in Fig. 6. Unpainted/unconsolidated specimens showed an average $\mathrm{rm}=0.7 \pm 0.2 \mathrm{mg} / \mathrm{cm}^{2}$, while painted/unconsolidated specimens reported $\mathrm{rm}$ values ranging from $2.0 \mathrm{up}$ to $4.3 \mathrm{mg} / \mathrm{cm}^{2}$.

These results suggest that the painted areas are those more susceptible to lose material because of the peeling action. Micro Acril seems to be more effective for all paint mixtures, except for those paints containing Arabic gum as binder. Probably, the organic origin of the gum made difficult to the acrylic polymer to penetrate into the stone and for this reason the final cohesion results to low. NanoEstel achieved poor performances, in some cases the treated specimens showed greater $\mathrm{rm}$ values with
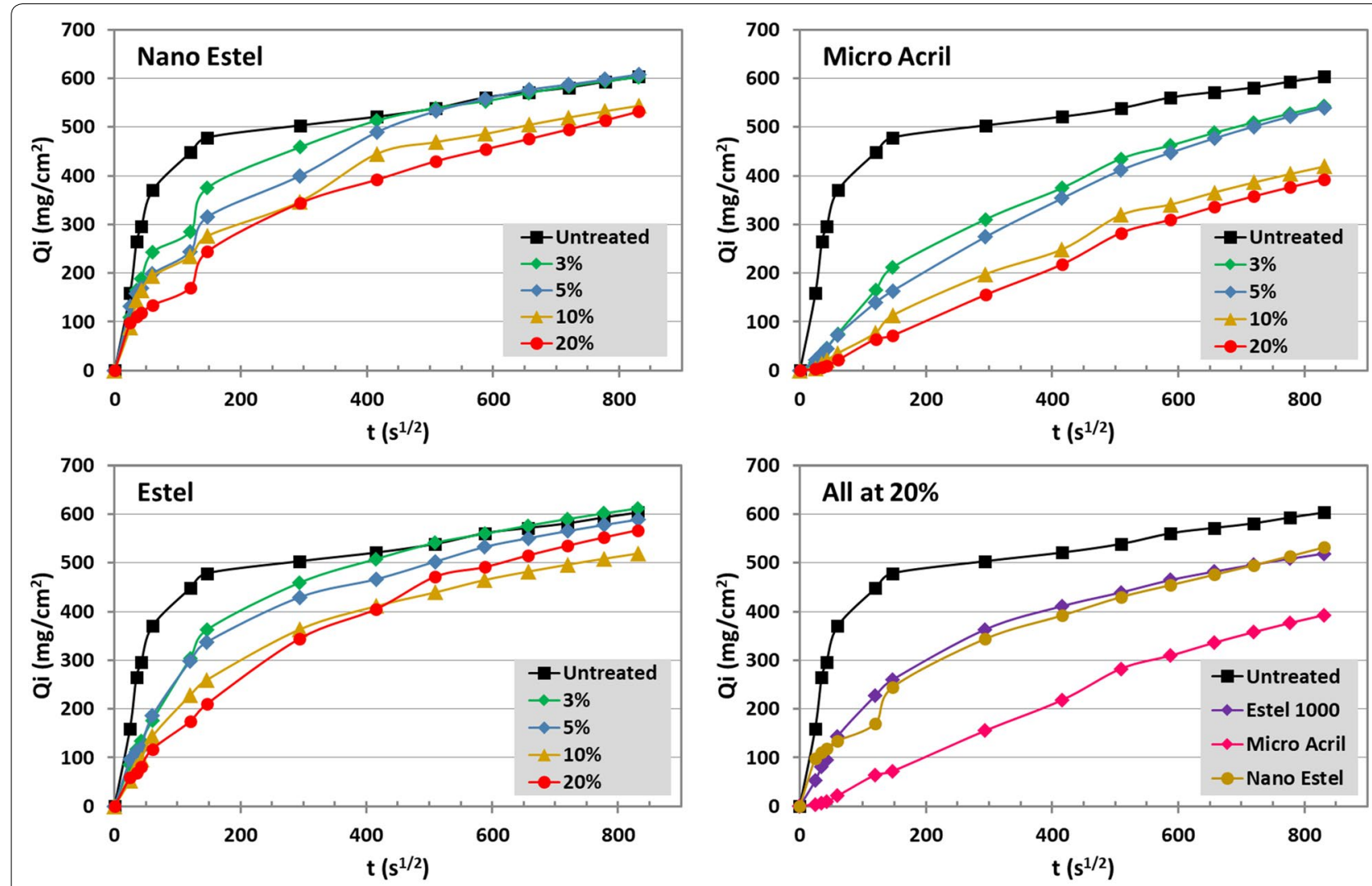

Fig. 5 Capillarity water absorption test carried on treated and untreated ignimbrite specimens 

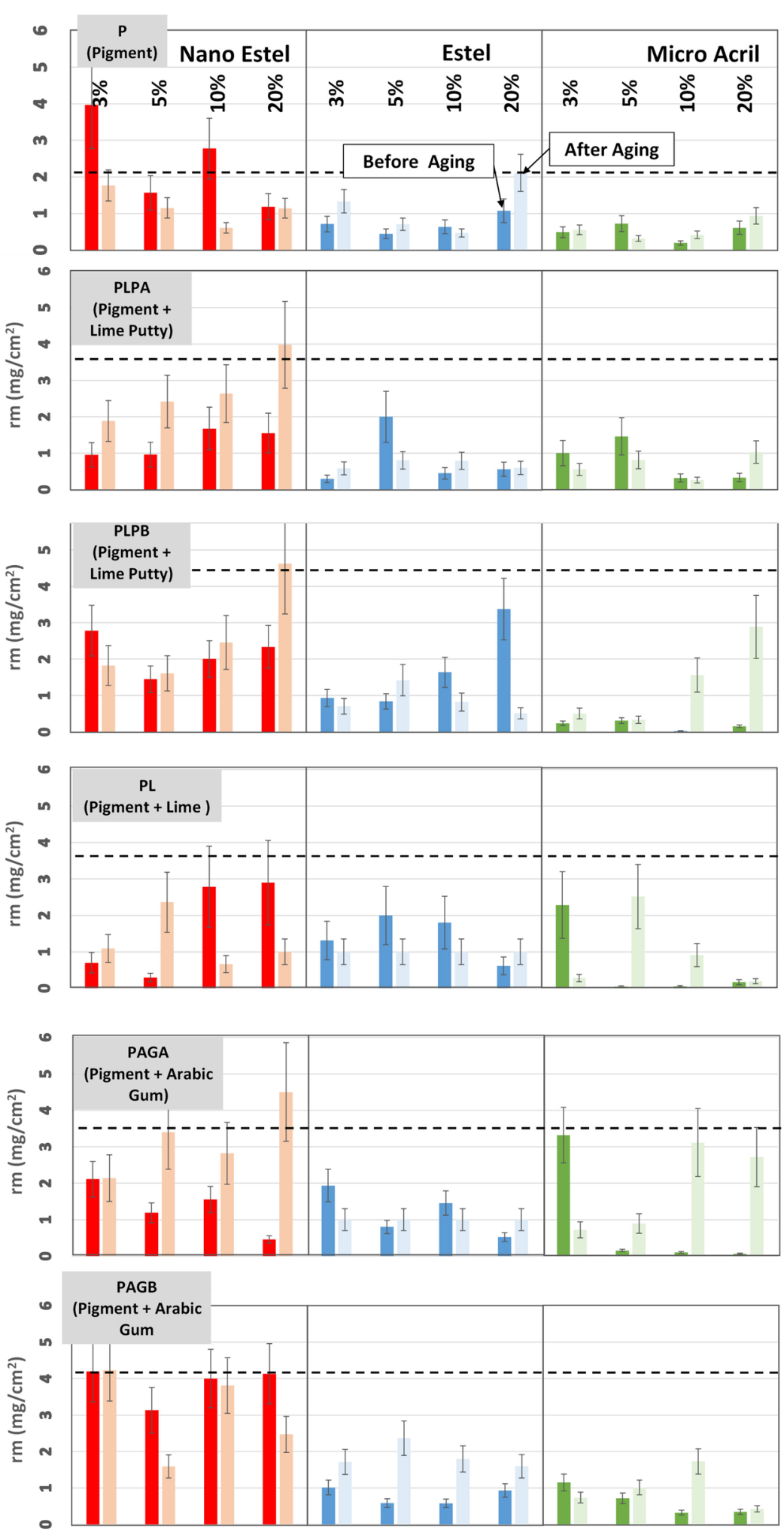

Fig. 6 Summary of scotch tape test measurements. The rm value observed for unpainted and unconsolidated specimens is $0.7 \pm 0.2 \mathrm{mg} / \mathrm{cm}^{2}$. The horizontal dashed line in each chart represents the rm value observed for painted but unconsolidated specimens 

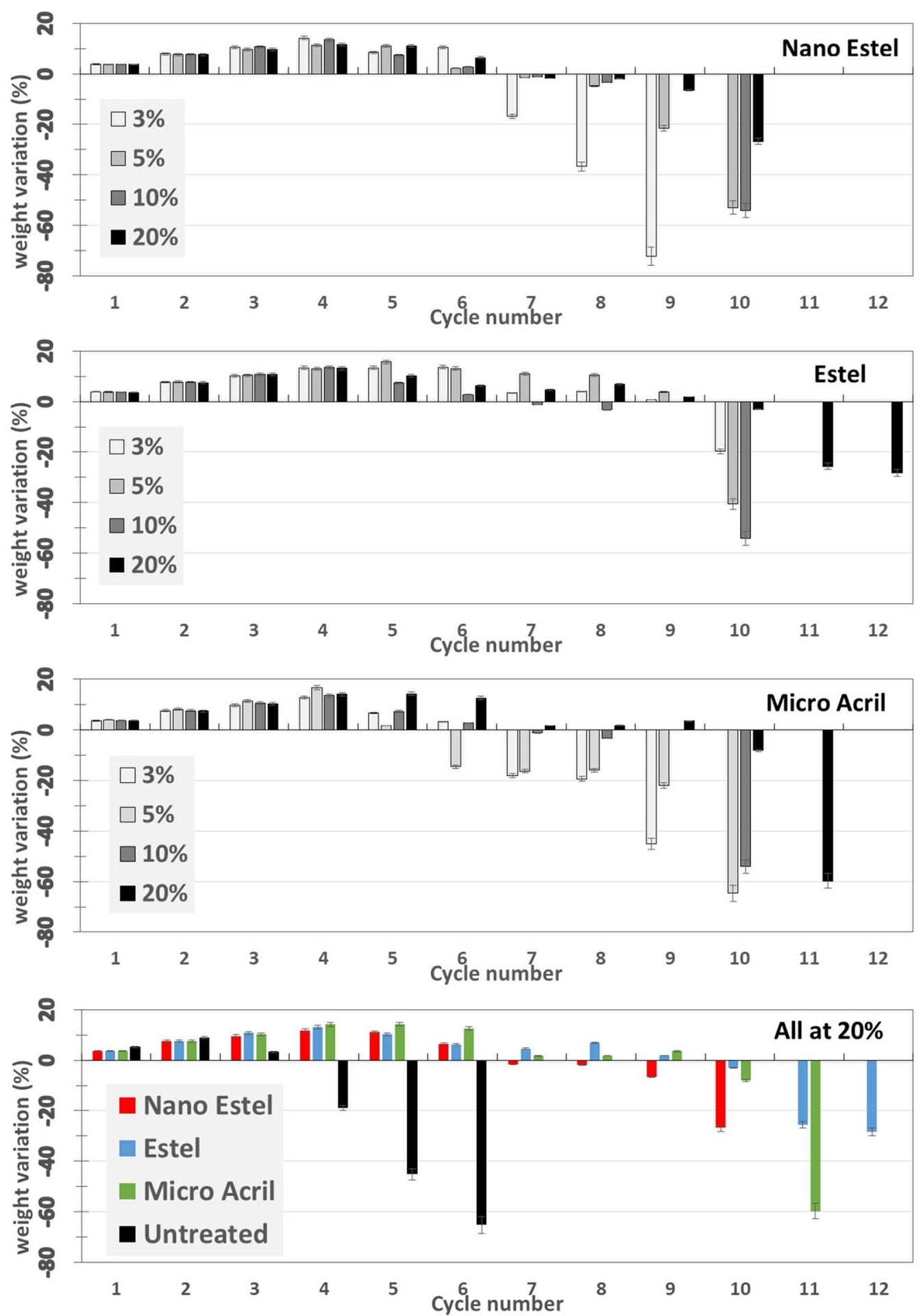

Fig. 7 Weight variations of samples measured during salt crystallization tests

respect to unconsolidated ones. This is probably because an aliquot of consolidant remains on the surface and is easily removed by the peeling. Estel (ethyl silicate) seems to be the most effective treatment, likely thanks to the better penetration; it is worth to remind that it is a product diluted in solvent, and not a suspension as for Micro 
Acril and NanoEstel. The effect of the aging is not fully clear, since in some cases the resistance of the surface increase, while in some other it is quite lower, and some other cases it seems to be the same as the unaged.

Salt crystallization represents a threat for the integrity of the stone [21,22], in particular ignimbrite suffers this kind of degradation [23]. The effect of the treatments as a function of the resistance versus salt weathering was explored in laboratory only on specimens painted with pigment without any binder. Figure 7 shows the weight variations recorded after each cycle of salt crystallization. An increasing of the weight is detected at earlier cycles. This is due to the salt which crystallizes into the porous structure without causing a detectable decay of the stone. In untreated samples, a weight loss is evident only after the fourth cycle, whereas, this evidence is postponed up the tenth cycle in treated ones. In some cases, the break of the sample was observed rather than a simple loss of material; in these cases, the measurement was stopped (i.e. NanoEstel 3\% up the 9th cycle). All treatments improve the resistance of the stone against salt weathering, untreated samples lose up to $60 \%$ of their weight. Treatments, in particular, those at higher concentrations lead to a lower weight loss and at later crystallization cycles. Estel treatments seems to induce a better resistance.

\section{Conclusions}

Tituli Picti represent an ancient form of urban graffiti in the archaeological town of Pompeii. Their conservation is still an open challenge. In this paper, we provided some insights on the use of some consolidating products be able to make such paints more resistant against degrading agents. The executive technique of the original Tituli Picti is still unclear, so in our research, several hypothesised paints mixture were reproduced on ignimbrite specimens. In particular, red ochre was used as pigment; lime putty, lime and Arabic gum were used as binders. These paints were washed out to reproduce the natural aging of the Tituli Picti.

Our results support the evidence that they were made just with pigment without any binder. Moreover, three consolidating products were tested to identify the most suitable to provide more resistance to the stone, with particular reference to the superficial portion. Nanosilica, ethyl silicate and an aqueous acrylic microemulsion were applied in this experimentation. After microscopic observations, colorimetric tests, superficial and bulk cohesion assessments, results suggest that ethyl silicate shows a well-balanced behaviour and seems to be the most appropriate product for the consolidation and the conservation of Tituli Picti.

\section{Supplementary information}

Supplementary information accompanies this paper at https://doi. org/10.1186/s40494-020-00393-0.

Additional file 1: Table S1. Summary of the consolidation treatments carried out on the painted specimens. Figure S1. Arrangement of the washout test, samples were immersed in deionized water and a vortex were generated by means of a magnetic stirrer.

\section{Acknowledgements}

We would like to thank the reviewers for their comments helping us improving the article.

\section{Authors' contributions}

$M O, R P, N R u$ conceived the research; SAR, MFR, MR, VC, DM, W designed the research and wrote the original draft; $L R, A A, N R O, A P$ performed the experiments and statistical analyses. All the authors reviewed, edited, and approved the final draft. All authors read and approved the final manuscript.

\section{Funding}

This research belongs to the framework of the project "Tituli Picti in the archaeological site of Pompeii: diagnostic analysis and conservation strategies" financially supported by the Planning Secretariat of the Archaeological Park of Pompeii.

\section{Availability of data and materials}

All data generated or analysed during this study are included in this published article [and its Additional file 1].

\section{Competing interests}

The authors declare that they have no competing interests.

\section{Author details}

${ }^{1}$ Department of Biology, Ecology and Earth Sciences, University of Calabria, via P. Bucci Cubo 12B, Arcavacata di Rende, CS 87036, Italy. ${ }^{2}$ Department of Mathematical and Computer Sciences, Physical Sciences and Earth Sciences (MIFT), University of Messina, Viale Ferdinando Stagno D'Alcontres 31, Messina 98166, Italy. ${ }^{3}$ General Director, Archaeological Park of Pompeii, via Plinio 4, Pompeii, NA 80045, Italy. ${ }^{4}$ Ecole Normale Supérieure-PSL, Laboratoire AOrOc Archéologie et Philologie d'Orient et d'Occident, UMR 8546, 45 rue d'Ulm, Paris 75005, France. ${ }^{5}$ Technical Planning Secretariat of the Archaeological Park of Pompeii, via Villa dei Misteri 2, Pompei, NA 80045, Italy.

Received: 16 January 2020 Accepted: 16 May 2020

Published online: 29 May 2020

\section{References}

1. http://pompeiisites.org/parco-archeologico-di-pompei/dati-visitatori/ (2019).

2. Senatore MR, Ciarallo A, Stanley JD. Pompeii damaged by volcaniclastic debris flows triggered centuries prior to the 79 AD. Vesuvius eruption (2014). Geoarchaeology. 2014;29(1):1-15.

3. Miriello D, Bloise A, Crisci GM, De Luca R, De Nigris B, Martellone A, Osanna M, Pace R, Pecci A, Ruggieri N. Non-destructive multi-analytical approach to study the pigments of wall painting fragments reused in mortars from the archaeological site of Pompeii (Italy). Minerals. 2018;8(4):134.

4. De Vos A, De Vos M. Pompei. Laterza: Ercolano e Stabia. Guide Archeologiche; 1982.

5. Vetter, E., 1953, Handbuch der italischen Dialekte, Heildelberg.

6. Varone, A., Stefani, G., 2009, Titolorum Pictorum Pompeianorum qui in CIL vol IV collecti sunt. Imagines, (Studi della Soprintendenza archeologica di Pompei, 29), Roma. 
7. Antonini, R., 2007, Contributi pompeiani II-IV: Quaderni di Studi Pompeiani 1 (2007), pp.47-113.

8. Capurso, A., 2016, Indagini e restauro dei monumenti di Pompei in Ignimbrite Campana con iscrizioni dipinte, in Rivista di Studi Pompeiani, ISSN 1120-3579, n.XXVI-XXVII (2015-2016), L'ERMA di BRETSCHNEIDER Roma, pp. 135-138.

9. Ruggieri, N., Maio, A.,Valentini, M., Nuzzo, M., 2016, Analisi del supporto murario e attività di diagnostica per la conservazione dei Tituli Picti sui fronti stradali, in Rivista di Studi Pompeiani, ISSN 1120-3579, n.XXVI-XXVII (2015-2016), L'ERMA di BRETSCHNEIDER Roma, pp. 138-139.

10. Peterse, K., de Waele, J., 2005, The Standardized Design of the Casa degli Scienziati $(V I$ 14, 43) in Pompeii: S.T.A.M. Mols, Moorman E.M., Omni pede stare. Saggi architettonici e circumvesuviani in memoriam Jos De Waele (Studi della Soprintendenza Archeologica di Pompei, 9), Napoli, pp. 197-227.

11. Langella A, Bish DL, Cappelletti P, Cerri G, Colella A, de Gennaro R, Graziano SF, Perrotta A, Scarpati C, de Gennaro M. New insights into the mineralogical facies distribution of Campanian Ignimbrite, a relevant Italian industrial material. Appl Clay Sci. 2013;72:55-73.

12. De'Gennaro, M., Colella, C., Langella, A., Cappelletti, P. Decay of Campanian ignimbrite stoneworks in some monuments of the Caserta area (1995) Science and Technology for Cultural Heritage, 4 (2), pp. 75-86.

13. Langella, A., Calcaterra, D., Cappelletti, P., Colella, A., D'Albora, M.P., Morra, V., de Gennaro, M.D. Lava stones from neapolitan volcanic districts in the architecture of campania region, Italy. Environ Earth Sci. 2009.59 (1), pp. $145-160$.

14. Rovella, N., Arcudi, A., Crupi, V., La Russa, M.F., Majolino, D., Osanna, M., Pace, R., Ruffolo, S.A., Ricca, M., Ruggieri, N., Venuti, V. Tituli Picti in the archaeological site of Pompeii: diagnostic analysis and conservation strategies (2018) European Physical Journal Plus, 133 (12), art. no. 539.

15. Casadio, F., Giangualano, I., Piqué, F. Organic materials in wall paintings: the historical and analytical literature (2004) Studies in Conservation, 49:sup1.

16. ISO/CIE 11664-4:2019 Colours and measurement of light.

17. UNI EN 15801:2010 Materiali lapidei naturali ed artificiali determinazione dell'assorbimento d'acqua per capillarità.

18. EN 1237:2001 Determination of resistance to salt crystallisation.

19. Drdácký M, Lesák J, Rescic S, Slížková Z, Tiano P, Valach J. Standardization of peeling tests for assessing the cohesion and consolidation characteristics of historic stone surfaces. Mater Struc. 2012;45(4):505-20.

20. G. Wheeler Alkoxysilanes and the Conservation of Stone The Getty Conservation Institute, Getty Publications, Los Angeles, USA (2005).

21. Zehnder K, Arnold A. Crystal growth in salt efflorescence. J Crystal Growth. 1989:97(2):513-21.

22. La Russa MF, Ruffolo SA, Belfiore CM, Aloise P, Randazzo L, Rovella N, Pezzino A, Montana G. Study of the effects of salt crystallization on degradation of limestone rocks. Periodico di Mineralogia. 2013;82(1):113-27.

23. La Russa MF, Ruffolo SA, de Buergo MÁ, Ricca M, Belfiore CM, Pezzino A, Crisci GM. The behaviour of consolidated Neapolitan yellow Tuff against salt weathering. Bull Eng Geol Environ. 2017;76(1):115-24.

\section{Publisher's Note}

Springer Nature remains neutral with regard to jurisdictional claims in published maps and institutional affiliations.

\section{Submit your manuscript to a SpringerOpen ${ }^{\circ}$ journal and benefit from:}

- Convenient online submission

- Rigorous peer review

- Open access: articles freely available online

- High visibility within the field

- Retaining the copyright to your article

Submit your next manuscript at $\boldsymbol{\nabla}$ springeropen.com 